\title{
Usefulness of Omalizumab in Rapid Drug Desensitization in Patients With Severe Anaphylaxis Induced by Carboplatin: Open Questions
}

Sánchez-Morillas L ${ }^{1}$, Casado Herráez A², Rubio-Perez $\mathrm{M}^{3}$, Robledo Echarren $\mathrm{T}^{4}$, González Gutiérrez $\mathrm{ML}^{4}$, Cimarra $\mathrm{M}^{4}$, Vázquez Cortés $\mathrm{S}^{1}$, Cerecedo $\mathrm{I}^{1}$, Fernández-Rivas $\mathrm{M}^{5}$ ${ }^{1}$ Allergology Department, Hospital Clínico San Carlos, IdISSC, ARADyAL RD16/0006/0009, Madrid, Spain

${ }^{2}$ Medical Oncology Department, Hospital Clínico San Carlos, UCM, IdISSC, Madrid, Spain

${ }^{3}$ Allergology Department, Hospital Infanta Sofia, Madrid, Spain ${ }^{4}$ Allergology Department, Hospital Clínico San Carlos, IdISSC, Madrid, Spain

${ }^{5}$ Allergology Department, Hospital Clínico San Carlos, IdISSC, UCM, ARADyAL RD16/0006/0009, Madrid, Spain

J Investig Allergol Clin Immunol 2020; Vol. 30(4): 298-300 doi: $10.18176 /$ jiaci.0499

Key words: Chemotherapeutic drugs. Carboplatin. Omalizumab. Rapid drug desensitization.

Palabras clave: Fármacos quimioterápicos. Carboplatino. Omalizumab. Desensibilización rápida.

Carboplatin is an effective and well-tolerated chemotherapeutic agent used as first-line and subsequent treatment for ovarian cancer. Hypersensitivity reactions to chemotherapy have increased in frequency in the last 20 years, thus preventing the use of first-line therapies and causing a negative impact on patient survival and quality of life $[1,2]$.

Omalizumab is a recombinant humanized anti-IgE monoclonal antibody approved for the treatment of severe allergic asthma and recurrent chronic idiopathic urticaria. It has been studied as an add-on therapy in food allergy, oral immunotherapy for food allergy, atopic dermatitis, idiopathic anaphylaxis, and mastocytosis [3].

We present 2 cases of severe anaphylaxis to carboplatin in which omalizumab was used to prevent reactions during rapid drug desensitization (RDD).

The first patient was a 57-year-old woman diagnosed with ovarian adenocarcinoma who had initially been treated with 6 cycles of carboplatin and paclitaxel without complications. A local recurrence developed 1 year later, and the patient started carboplatin and gemcitabine. During the second cycle of carboplatin (eighth exposure), she developed palmar pruritus and generalized erythematous rash that resolved with dexchlorpheniramine and methylprednisolone. With the following cycle (ninth exposure), she developed palmar pruritus, generalized erythematous rash, nausea, and vomiting and reported a sense of impending doom. Her blood pressure was $60 / 30 \mathrm{mmHg}$ and her heart rate was $40 \mathrm{bpm}$. She was treated with intravenous dexchlorpheniramine, methylprednisolone, and intramuscular adrenaline. She also had epigastric pain radiating to the back, with ST segment 
elevation in leads V1 to V6, elevated troponin I $(0.14 \mathrm{ng} / \mathrm{mL})$, and normal creatinine kinase $\mathrm{MB}$. The patient was asymptomatic after 24 hours without treatment.

She was referred to our department for an allergological work-up. We carried out skin prick testing (SPT) $(10 \mathrm{mg} / \mathrm{mL}$ in saline solution) and intradermal testing (IDT) (1 and $10 \mathrm{mg} / \mathrm{mL}$ ) with carboplatin. The result of IDT was positive at $10 \mathrm{mg} / \mathrm{mL}$. Given the severity of the reaction and the positive IDT result, we considered RDD with omalizumab as an adjuvant. After giving her informed consent and with the approval of the institutional review board, the patient received a dose of $300 \mathrm{mg}$ of subcutaneous omalizumab and another dose of $150 \mathrm{mg} 7$ days later and every 14 days thereafter. Twenty-four hours after the second dose, we performed a 16-step RDD in the intensive care unit, as previously described [1]. The patient finally tolerated 6 cycles with the same protocol, each without complications.

The second patient was a 61-year-old woman diagnosed with breast and endometrial cancer who had previously been treated with chemotherapy and radiotherapy and started treatment with carboplatin and paclitaxel for a recurrence. During the third cycle (17th exposure to carboplatin), she experienced general malaise, blurred vision, nausea, hypotension, and severe bronchospasm. The symptoms resolved with treatment.

We performed SPT and IDT with carboplatin, as described in the previous patient. IDT was positive. Omalizumab was prescribed as an adjuvant for RDD using the protocol described above. The patient gave her written informed consent, and the procedure was approved by the institutional review board.

We administered 4 cycles of a 16-step RDD protocol, and the patient reacted in all of them. The reactions appeared at steps 12 (first cycle), 14 (second cycle), and 16 (third and fourth cycles), and all of them involved the skin exclusively, with manifestations ranging from palmar pruritus and facial erythema to a generalized rash only once. All the reactions resolved with intravenous antihistamines and corticosteroids, and the patient was able to finish the 4 cycles.

RDD enables safe readministration of a drug to which a patient has become allergic. The procedure is usually safe and effective, although there is an inherent risk of a severe or even fatal anaphylactic reaction when a medication to which a patient had presented a severe hypersensitivity reaction is reintroduced [1]. Both patients presented severe life-threatening reactions with serious cardiovascular involvement. We recommended a 16-step desensitization with carboplatin in an intensive care unit. However, both patients and their oncologists refused the drug owing to the severity of the previous reactions. Given that carboplatin is the most appropriate drug in patients with ovarian cancer, we decided to administer omalizumab as an adjuvant treatment in order to diminish the risk of a severe reaction during RDD. One patient tolerated RDD without experiencing a reaction, and the other presented mild skin reactions. We do not know whether they would have tolerated the RDD if omalizumab had not been administered as an adjuvant.

To our knowledge, there are only 6 publications on the beneficial effect of omalizumab as an adjuvant in drug desensitization protocols: 1 case report with insulin [4], 12 patients with aspirin [5,6], and 3 cases with chemotherapeutic agents [7-9]. The Table summarizes the latter 3 cases, together with the 2 cases we report.

Omalizumab dosing in allergic asthma is based on the patient's weight and total IgE, whereas in urticaria a 300-mg dose is given. All the patients desensitized to aspirin with addon omalizumab had asthma, and the dose was calculated as for the asthma indication and administered every 2-4 weeks for 16 weeks prior to desensitization $[5,6]$. However, when clinicians consider using omalizumab as an adjuvant in RDD to chemotherapy, they do not know what dose to administer and cannot pretreat patients for several months, because continuing

Table. Characteristics of Patients Who Received Omalizumab as Adjuvant Therapy During Rapid Desensitization to Chemotherapy Drugs

\begin{tabular}{|c|c|c|c|c|c|c|c|c|}
\hline Authors & Cases & Patient & $\begin{array}{l}\text { Drug } \\
\text { Allergy }\end{array}$ & Symptoms & $\begin{array}{c}\text { Dose of } \\
\text { Omalizumab }\end{array}$ & $\begin{array}{c}\text { No. of Doses of } \\
\text { Omalizumab } \\
\text { Before RDD }\end{array}$ & $\begin{array}{l}\text { No. of } \\
\text { RDD } \\
\text { Cycles }\end{array}$ & Tolerance \\
\hline $\begin{array}{l}\text { Cahill } \\
\text { et al [8] }\end{array}$ & 1 & $\begin{array}{c}68 \mathrm{y} \\
\text { (sex not } \\
\text { specified) }\end{array}$ & Oxaliplatin & Anaphylaxis & $150 \mathrm{mg} / 2 \mathrm{wk}$ & 2 doses & 4 & $\begin{array}{l}\text { Mild } \\
\text { reaction }\end{array}$ \\
\hline $\begin{array}{l}\text { Ojaimi } \\
\text { et al [7] }\end{array}$ & 1 & $\begin{array}{c}\text { Female } \\
63 \mathrm{y}\end{array}$ & Carboplatin & Anaphylaxis & $300 \mathrm{mg} / 2 \mathrm{wk}$ & 3 doses & 4 & $\begin{array}{l}\text { No } \\
\text { reaction }\end{array}$ \\
\hline Prieto et al [9] & 1 & $\begin{array}{l}\text { Female } \\
61 \mathrm{y}\end{array}$ & Oxaliplatin & Anaphylaxis & $300 \mathrm{mg} / 2 \mathrm{wk}$ & 1 dose & 6 & $\begin{array}{l}\text { No } \\
\text { reaction }\end{array}$ \\
\hline \multirow[t]{2}{*}{$\begin{array}{l}\text { Sánchez-Morillas } \\
\text { et al }\end{array}$} & 2 & $\begin{array}{l}\text { Female } \\
57 \mathrm{y}\end{array}$ & Carboplatin & Anaphylaxis & $\begin{array}{l}300 \mathrm{mg} \text { once. } \\
\text { After } 7 \mathrm{~d}, \\
150 \mathrm{mg} / 2 \mathrm{wk}\end{array}$ & 2 doses & 6 & $\begin{array}{l}\text { No } \\
\text { reaction }\end{array}$ \\
\hline & & $\begin{array}{l}\text { Female } \\
61 \mathrm{y}\end{array}$ & Carboplatin & Anaphylaxis & $\begin{array}{l}300 \mathrm{mg} \text { once. } \\
\text { After } 7 \mathrm{~d}, \\
150 \mathrm{mg} / 2 \mathrm{wk}\end{array}$ & 2 doses & 4 & $\begin{array}{l}\text { Mild } \\
\text { reaction }\end{array}$ \\
\hline
\end{tabular}

Abbreviations: RDD, rapid drug desensitization. 
with the chemotherapy regimen is more urgent. Consequently, the dose given is decided arbitrarily.

In all the cases reported in the Table, omalizumab was administered every 2 weeks, albeit at variable doses. Ojaimi et al [7] and Prieto-García et al [9] administered $300 \mathrm{mg}$, whereas Cahill et al [8] administered $150 \mathrm{mg}$. We administered $300 \mathrm{mg}$ followed 7 days later by $150 \mathrm{mg} / 2 \mathrm{wk}$. The patients described by Ojaimi et al and Prieto-García et al and patient \#1 in the present report tolerated all RDD cycles with omalizumab without reactions. In contrast, the patient reported by Cahill et al and patient $\# 2$ in the present report experienced mild reactions. While more data are needed, it seems that the 300$\mathrm{mg}$ dose is more effective than the $150-\mathrm{mg}$ dose. The number of doses of omalizumab administered before RDD varies from 1 to 3 .

In the light of currently available data, we suggest that omalizumab $300 \mathrm{mg}$ given every 2 weeks, and with at least 1 dose given before starting RDD, enables patients with severe anaphylaxis to platinum drugs to receive them safely. Adding omalizumab increases the treatment cost of gynecological cancer, although when platinum-based treatment is avoided, the second-line chemotherapy agents seem to be associated with reduced survival [2].

\section{Funding}

This work was supported by Instituto de Salud Carlos III (ISCIII) and cofunded by Fondo Europeo de Desarrollo Regional - FEDER for the Thematic Research Network ARADyAL (RD16/0006/0009).

\section{Conflicts of Interest}

Dr. Sánchez-Morillas reports personal fees from the Sociedad Madrid-Castilla La Mancha de Alergología e Inmunología Clínica, ALK, and Stallergenes.

Dr. Casado Herráez reports participating on advisory boards for Pharmamar, Lilly, Merck (MSD), EISAI, and Roche International and receiving consultancy fees from Pharmamar, Roche, and Lilly.

Dr. Rubio Pérez declares that she has no conflicts of interest.

Dr. Robledo Echarren reports personal fees from Sociedad Madrid-Castilla La Mancha de Alergología e Inmunología Clínica and GSK.

Dr. González Gutiérrez reports personal fees from Sociedad Española de Alergología e Inmunología Clínica, GSK, and Teva.

Dr. Cimarra reports personal fees from Sociedad MadridCastilla La Mancha de Alergología e Inmunología Clínica, Novartis, and ALK.

Dr. Vázquez Cortés reports personal fees from Novartis, Diater, SanofiAventis, and Sociedad Madrid-Castilla La Mancha de Alergología e Inmunología Clínica.

Dr. Cerecedo reports consultancy fees from Diater, Leti, ALK, and Stallergenes outside the submitted work and personal fees from Sociedad Madrid-Castilla La Mancha de Alergología e Inmunología Clínica, and grants from the Spanish Government (ISCIII). Dr. Cerecedo holds a patent (PCT/ES2014/070634).
Dr. Fernández-Rivas reports grant from the European Commission, grants from the Spanish Government (MINECO, ISCIII), personal fees from Aimmune, ALK, Allergy Therapeutics, Fundación SEAIC, HAL, Thermo Fisher Scientific, Schreiber foods, and DBV outside the submitted work. Dr. Fernández-Rivas holds a patent (PCT/ ES2014/070634).

\section{References}

1. Bonamichi-Santos R, Castells M. Desensitization for drug hypersensitivity to chemotherapy and monoclonal antibodies. Curr Pharm Des. 2016;22:6870-80.

2. Tsibulak I, Zeimet AG, Marth C. Hopes and failures in front-line ovarian cancer therapy. Crit Rev Oncol Hematol. 2019:143:14-9.

3. Dantzar JA, Wood RA. The use of omalizumab in allergen immunotherapy. Clin Exp Allergy. 2018;48:232-40.

4. Matheu $V$, Franco $A$, Pérez $E$, Hernández $M$, Barrios $Y$. Omalizumab for drug allergy. J Allergy Clin Immunol. 2007:120(6):1471-2.

5. Lang DM, Aronica MA, Maierson ES, Wang XF, Vasas DC, Hazen SL. Omalizumab can inhibit respiratory reaction during aspirin desensitization. Ann Allergy Asthma Immunol. 2018;121:98104.

6. Guillén D, Bobolea I, Calderón O, Fiandor A, Cabañas $R$, Heredia $R$, et al. Aspirin desensitization achieved after omalizumab treatment in a patient with aspirin-exacerbated urticarial and respiratory disease. J Invest Allergol Clin Immunol. 2015;25(2):133-5.

7. Ojaimi S, Harnett PR, Fulcher DA. Successful carboplatin desensitization by using omalizumab and paradoxical diminution of total IgE levels. J Allergy Clin Immunol Pract. 2014;2(1):105-6.

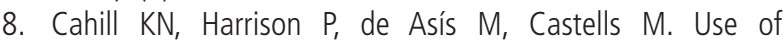
omalizumab to achieve successful desensitization after oxaliplatin anaphylaxis. J Allergy Clin Immunol. 2012;129(2):SupplementAB103.

9. Prieto-García A, Noguerado B, Rojas P, Torrado I, RodríguezFernández A, Tornero P. Unexpected anaphylaxis after completing a desensitization protocol to oxaliplatin: Successful adjuvant use of omalizumab. J Invest Allergol Clin Immunol. 2019;29(1):53-5.

Manuscript received December 5, 2019; accepted for publication February 18, 2020

Montserrat Fernández-Rivas

Allergology Department. Hospital Clínico San Carlos C/ Prof. Martín Lagos, s/n 28040 Madrid. Spain

E-mail: mariamontserrat.fernandez@salud.madrid.org 